\title{
Rumah Sakit Gigi Dan Mulut Pendidikan UMS Dengan Pendekatan Psikologi Arsitektur Di Surakarta
}

\author{
Khairunnisa Anggrainie, Agus Heru Purnomo, Dyah S. Pradnya P. \\ Program Studi Arsitektur \\ Jurusan Arsitektur Fakultas Teknik \\ Universitas Sebelas Maret Surakarta \\ Email : khairunnisaanggrainie@gmail.com
}

\begin{abstract}
Design of UMS Dental Hospital in Surakarta background by the increasing cases of oral disease in Surakarta, yet the presence of integrated service centers for cases of dental and oral diseases, unavailability of practice means for students of Dentistry UMS as well as a patient's fear problem will care done by a dentist is also a major issue in the establishment of UMS Dental Hospital. According to these issues, design problems that can be raised is how to design the UMS Dental Hospital with the foundation concepts that can create an effective healing environment with consideration of the state of the entire user psychology to support all activities by implementing architectural psychology emphasis. In the healing process of patients, psychiatric therapy is an effective method for accelerating the healing process, so with an emphasis on the Psychology Architecture produce UMS Dental Hospital design that can create a comfortable atmosphere and eliminate eerie impression of dental care and can facilitate all activities of UMS Dental Hospital users by applying the principles of psychology architecture to help the healing process of patients both physically and mentally.
\end{abstract}

Keywords: Hospital, Dental Hospital, UMS Dental Hospital, Psychological Architecture

\section{PENDAHULUAN}

Mulut merupakan organ yang penting pada tubuh menusia. Mulut adalah gerbang masuknya segala macam penyakit. Keadaan rongga mulut yang tidak sehat dapat menyebabkan kelainan pada organ lain. Infeksi masuk lewat gigi dan mulut dan kemudian menjalar ke organ-organ lain. Untuk itu, perawatan kesehatan gigi dan mulut sangat dianjurkan sedini mungkin untuk diberikan secara berkala.

Selama ini kesadaran masyarakat Indonesia akan pentingnya kesehatan gigi dan mulut masih relatif rendah bila dibandingkan dengan negara-negara lainnya. Banyak masyarakat Indonesia enggan memeriksakan kesehatan gigi, bahkan tidak sedikit pula yang takut berobat ke dokter gigi.

Data Profil Kesehatan Jawa Tengah Departemen Kesehatan tahun 2012 menyebutkan bahwa jumlah tumpatan gigi tetap tahun 2012 sebanyak 135.710, sementara jumlah pencabutan gigi tetap sebanyak 138.355. Data tersebut menandakan bahwa motivasi masyarakat dalam mempertahankan gigi geligi belum maksimal, oleh karena itu masih diperlukan penyuluhan yang terus menerus agar masyarakat memeriksakan gigi secara teratur. Upaya ini sekaligus menuntut tersedianya pelayanan kesehatan yang memadai di setiap daerah. Di sisi lain peningkatan pelayanan kesehatan gigi masyarakat menuntut adanya sumber daya manusia yang berkualitas dan memiliki spesialisasi di bidang kesehatan gigi yaitu dokter gigi.

Menurut data Konsil Kedokteran Indonesia/KKI per 31 desember 2012 persebaran dokter gigi dan dokter gigi spesialis di Jawa Tengah masih sangat minim. Dari semua provinsi di Pulau Jawa, Jawa Tengah merupakan provinsi dengan dokter gigi dan dokter gigi spesialis terendah. Dengan keadaan penduduk yang padat dan kurangnya persebaran dokter gigi tersebut, diperlukan suatu sarana untuk meningkatkan jumlah tenaga kerja dokter gigi ahli di Surakarta. Universitas Muhammadiyah Surakarta merupakan lembaga pendidikan tinggi pertama di 
Surakarta yang memiliki Program Studi Ilmu Kedokteran Gigi. Program Studi Kedokteran Gigi UMS baru didirikan sejak 2010. Program studi ini nantinya akan mencetak tenaga kerja dokter gigi yang terampil di daerah Surakarta, akan tetapi Program Studi Kedokteran Gigi UMS tidak memiliki sarana yang memadai. Program studi ini tidak memiliki laboratorium klinik yang dapat dipergunakan untuk melanjutkan studi keprofesian. Mahasiswa yang sudah lulus studi teori dan mendapatkan gelar Sarjana Kedokeran Gigi seharusnya melanjutkan ke tahap profesi di kampus masing-masing dengan cara praktik pada 8 jenis laboratorium klinik. Tetapi Program Studi Kedokteran Gigi UMS hanya memiliki 1 klinik gigi yang nantinya akan dipakai untuk 8 jenis penanganan penyakit. Keadaan ini sangat memprihatinkan mengingat bahwa Prodi Kedokteran Gigi UMS adalah satu-satunya sarana pendidikan yang akan menghasilkan tenaga ahli penyakit gigi di Surakarta.

Kebutuhan akan RSGMP ini juga diperkuat dengan adanya surat keputusan menteri kesehatan RI No. H.K.00.05.1.4.492.A pada tahun 2002 yang berisi bahwa setiap Fakultas Kedokteran Gigi harus memiliki Rumah sakit gigi dan mulut pendidikan dalam upaya untuk meningkatkan kualitas dokter gigi dan pelayanan kepada masyarakat umum dan Standar Pendidikan Profesi Dokter Gigi yang ditetapkan oleh Konsil Kedokteran Indonesian pada $\mathrm{Bab} \mathrm{V}$ dan $\mathrm{Bab}$ VI yaitu tentang ketersediaan sarana dan prasarana pendidikan, laboratorium dental, dan oral biologi serta fasilitas kepaniteraan klinik.

Berdasarkan uraian yang telah disebutkan, perlu adanya suatu rumah sakit gigi dan mulut di Surakarta yang mampu mencakup segala kegiatan medis, nonmedis, penunjang medis, penunjang nonmedis serta pendidikan di Kota Surakarta. Fasilitas yang terdapat pada Rumah Sakit Gigi dan Mulut Pendidikan tersebut juga harus mengacu pada fasilitas yang dapat membantu proses penyembuhan baik secara fisik maupun psikologi.

Tujuan dari perencanaan dan perancangan Rumah Sakit Gigi dan Mulut Pendidikan UMS di Surakarta ini adalah memberikan wadah bagi kegiatan belajar mengajar dan praktik ilmu kesehatan gigi kepada masyarakat umum di Program Studi Kedokteran Gigi UMS dengan menggunakan penekanan Psikologi Arsitektur sehingga dapat menciptakan suasana yang mendukung bagi keberhasilan proses belajar mengajar, serta menjadikan Rumah Sakit Gigi dan Mulut Pendidikan UMS sebagai pelayanan terpadu kesehatan gigi dan mulut di kota Surakarta yang dapat merespon kebutuhan pasien serta mengurangi gejala takut akan perawatan gigi dengan menggunakan penekanan psikologi arsitektur.

\section{METODE}

Metoda pembahasan yang dilakukan untuk tahapan pembuatan konsep perencanaan dan perancangan Rumah Sakit Gigi dan Mulut Pendidikan UMS dengan Penekanan Psikologi Arsitektur sebagai berikut.

A. Penelusuran Masalah

Tahap penelusuran masalah merupakan pemberangkatan ide awal untuk mengangkat tema atau topik yang terpilih untuk penulisan konsep perencanaan dan perancangan Rumah Sakit Gigi dan Mulut Pendidikan UMS dengan Penekanan Psikologi Arsitektur.

B. Pengumpulan Informasi dan Data

1. Informasi

Studi literatur merupakan tahapan mencari informasi melalui buku-buku referensi, situs-situs internet, atau hasil penilitian yang terkait dengan judulyang diajukan. Studi literatur tersebut terdiri dari

a. Pemahaman rumah sakit gigi dan mulut pendidikan;

b. Karakteristik penyandang penyakit gigi dan mulut;

c. Psikologi rsitektur;

d. Data pasien dan fasilitas sarana kesehatan di Surakarta

\section{Data}
a. Wawancara
Wawancara berupa pengumpulan data yang dibutuhkan untuk mengetahui informasi tentang psikologi pasien dan juga kebutuhan akan ruang melalui 
narasumber yang berkaitan, yaitu pelaku yang berkepentingan.

b. Survey lapangan

Metode survey lapangan bertujuan mengetahui kondisi di lapangan mengenai gambaran karakteristik dari pola pemanfaatan ruang pada Rumah Sakit Gigi dan Mulut Pendidikan UMS dengan Penekanan Psikologi Arsitektur. Selain itu survey lapangan juga digunakan untuk mengetahui kondisi fisik kawasan yang akan dijadikan tapak meliputi keadaan fisik-sosial kawasan, topografi, letak geografis, jaringan infrastruktur, serta potensi lingkungan lokasi perencanaan.

c. Analisis Penekanan Konsep Perencanaan dan Perancangan serta Analisis Psikologi Arsitektur Tahapan analisis ini dilakukan dengan analisis data menggunakan metode analisis deskriptif yaitu melalui penguraian data yang disertai gambar sebagai media berdasar pada teori normatif yang ada serta bagan-bagan alur. Tahapan analisis merupakan tahap pengolahan data yang telah terkumpul dan dikelompokan berdasarkan pemrograman fungsional, performansi, dan arsitektural.

d. Sintesa

Tahap sintesa penyatuan antara keseluruhan data dan hasil analisis untuk mencapai tujuan dan sasaran yang telah ditetapkan. Data dan analisis diolah dengan ketentuan atau persyaratan perencanaan dan perancangan yang pada akhirnya seluruh hasil olahan dikembangkan menjadi konsep rancangan yang siap ditransformasikan pada bentuk fisik yang dikehendaki.

e. Konsep Perencanaan dan Perancangan

Proses analisis dan sintesa arsitektural akan dihasilkan beberapa konsep yaitu konsep lokasi dan tapak, konsep peruangan, konsep tampilan bangunan, konsep utilitas dan struktur bangunan Rumah Sakit Gigi dan Mulut Pendidikan UMS.

\section{ANALISIS}

\subsection{Analisis Peruangan}

Tabel 1.Kebutuhan Ruang

\begin{tabular}{|c|c|c|}
\hline \multicolumn{2}{|c|}{ PELAKU } & PERUANGAN \\
\hline \multirow[t]{4}{*}{$\begin{array}{l}\text { Pengunjung } \\
\text { dan pasien }\end{array}$} & $\begin{array}{l}\text { Pengunjung } \\
\text { umum }\end{array}$ & \\
\hline & $\begin{array}{l}\text { Pasien Gawat } \\
\text { Darurat }\end{array}$ & $\begin{array}{l}\text { Instalasi Gawat } \\
\text { Darurat }\end{array}$ \\
\hline & $\begin{array}{l}\text { Pasien Rawat } \\
\text { jalan/ Klinik } \\
\text { Khusus } \\
\end{array}$ & R. Klinik Khusus \\
\hline & $\begin{array}{l}\text { Pasien Klinik } \\
\text { Mahasiswa }\end{array}$ & $\begin{array}{l}\text { R. Laboratorium } \\
\text { Klinik Mahasiswa }\end{array}$ \\
\hline \multirow[t]{2}{*}{ Mahasiswa } & $\begin{array}{l}\text { Mahasiswa } \\
\text { Kuliah Umum }\end{array}$ & R. Kuliah Umum \\
\hline & $\begin{array}{l}\text { Mahasiswa } \\
\text { Praktikum }\end{array}$ & $\begin{array}{l}\text { R. Praktikum } \\
\text { Preklinik }\end{array}$ \\
\hline \multirow[t]{2}{*}{ Dosen } & Praktik Profesi & R. Klinik Khusus \\
\hline & Mengajar & R.Diskusi \\
\hline $\begin{array}{l}\text { Pengelola } \\
\text { RSGMP }\end{array}$ & $\begin{array}{l}\text { Direksi } \\
\text { RSGMP }\end{array}$ & $\begin{array}{l}\text { R. Pengelola } \\
\text { RSGMP }\end{array}$ \\
\hline \multirow[t]{4}{*}{$\begin{array}{l}\text { Staff dan } \\
\text { Karyawan }\end{array}$} & $\begin{array}{l}\text { Operasional } \\
\text { Tenaga medis }\end{array}$ & R. Periksa \\
\hline & $\begin{array}{l}\text { Operasional } \\
\text { tenaga medis } \\
\text { farmasi }\end{array}$ & Apotek \\
\hline & $\begin{array}{l}\text { Unit Lab. } \\
\text { Teknik }\end{array}$ & Lab. Teknik Gigi \\
\hline & Unit Radiologi & R. Rontgent \\
\hline \multirow[t]{3}{*}{$\begin{array}{l}\text { Tenaga } \\
\text { Teknis }\end{array}$} & $\begin{array}{l}\text { Cleaning } \\
\text { service }\end{array}$ & Janitor \\
\hline & Security & Pos Satpam \\
\hline & $\begin{array}{l}\text { Petugas } \\
\text { Maintenance } \\
\text { ME }\end{array}$ & R. ME \\
\hline
\end{tabular}

\subsection{Analisis Kegiatan}

Kegiatan yang akan diwadahi dalam RSGMP UMS adalah.

1) Kegiatan pelayanan medik dan perawatan

2) Kegiatan penunjang

3) Kegiatan belajar mengajar

4) Kegiatan administrasi

5) Kegiatan servis 


\subsection{Analisis Besaran Ruang}

Tabel 2.Rekapitulasi Besaran Ruang

\begin{tabular}{|c|c|}
\hline Fasilitas & Luasan \\
\hline Fasilitas Penerima & $102 \mathrm{~m}^{2}$ \\
\hline $\begin{array}{l}\text { Fasilitas Pelayanan Medik IGD dan } \\
\text { Klinik khusus }\end{array}$ & $410 \mathrm{~m}^{2}$ \\
\hline $\begin{array}{l}\text { Fasilitas Pellayanan } \\
\text { Laboratorium klinik }\end{array}$ & $896 \mathrm{~m}^{2}$ \\
\hline Fasilitas Akademik & $671,5 \mathrm{~m}^{2}$ \\
\hline Fasilitas Penunjang Medis & $166 \mathrm{~m}^{2}$ \\
\hline Fasilitas Penunjang non Medis & $951 \mathrm{~m}^{2}$ \\
\hline Fasilitas Pengelola & $189 \mathrm{~m}^{2}$ \\
\hline Fasilitas Service & $278 \mathrm{~m}^{2}$ \\
\hline Fasilitas Parkir & $3330 \mathrm{~m}^{2}$ \\
\hline TOTAL & $6993,5 \mathrm{~m}^{2}$ \\
\hline
\end{tabular}

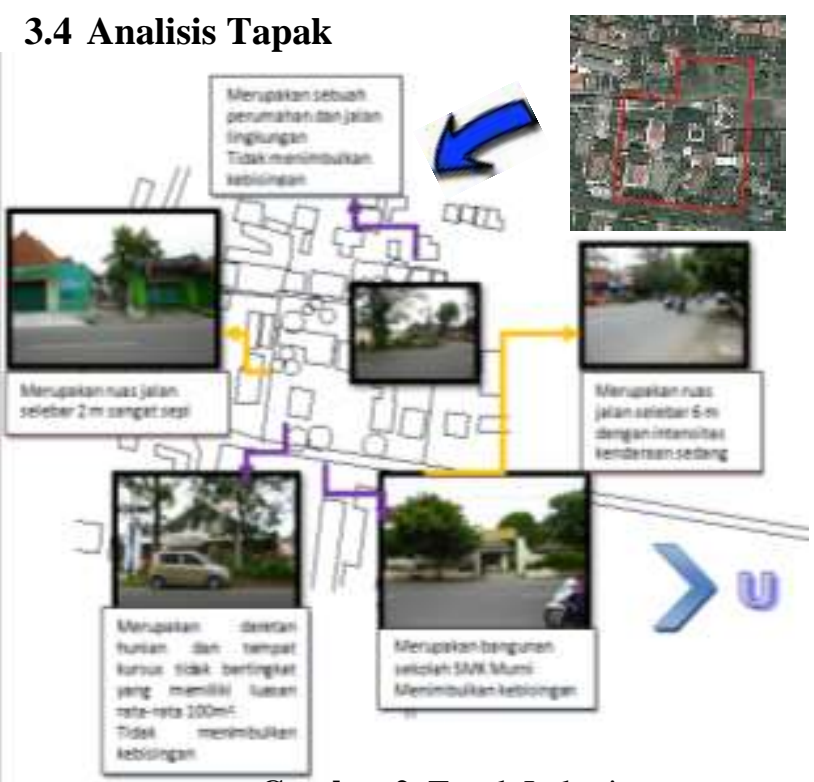

Gambar 2. Tapak Lokasi

Tapak yang dipilih untuk pendirian RSGMP UMS adalah tapak yang dimiliki oleh Universitas Muhammadiyah Surakarta yang sudah direncanakan akan dipakai untuk pembangunan RSGMP UMS beberapa tahun kedepan.

Batas tapak

Utara : Pemukiman
Timur : Jalan Utama (Jl. Dr.
Wahidin), SMK Murni
Selatan : Jalan Lingkungan,
pemukiman
Barat : Pemukiman

\subsection{Analisis Pengolahan Tapak 3.5.1 Analisis Pencapaian}

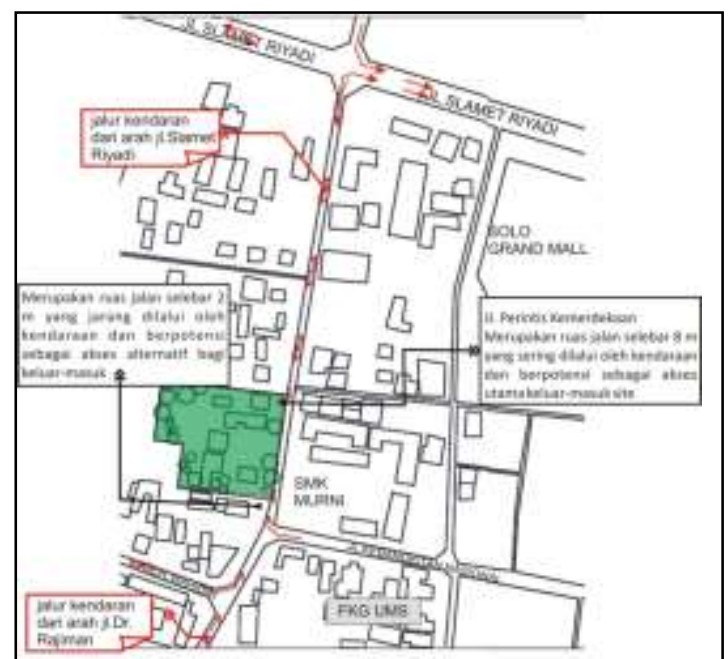

Gambar 3. Pencapaian Tapak dari Jalan Besar

Dari analisis di atas didapatkan respon desain yaitu :

Sirkulasi ambulans dibuat searah mengarah langsung ke sisi samping tapak di mana terdapat IGD. Ambulans keluar melalui pintu masuk samping di sisi selatan tapak bersamaan dengan pintu keluar motor pengunjung.

Untuk kegawat daratan pasien, pasien akan langsung diantarkan ke rumah sakit rujukan dengan menggunakan ambulans, untuk itu parkir ambulans terletak dekat dengan pintu masuk IGD.

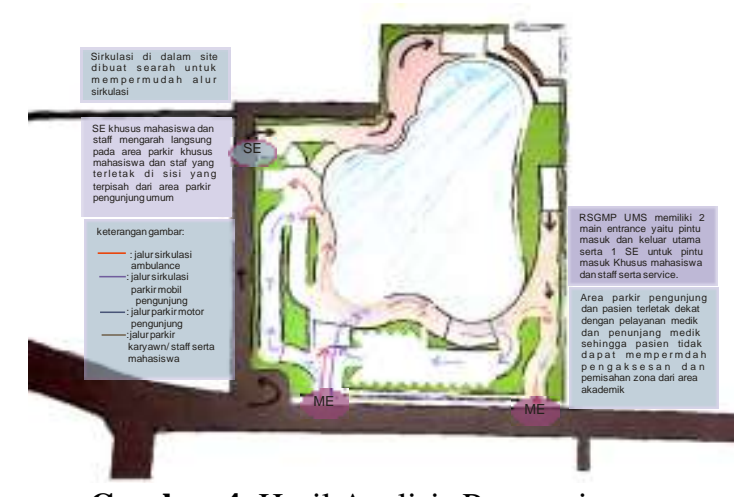

Gambar 4. Hasil Analisis Pencapaian 


\subsubsection{Analisis View}

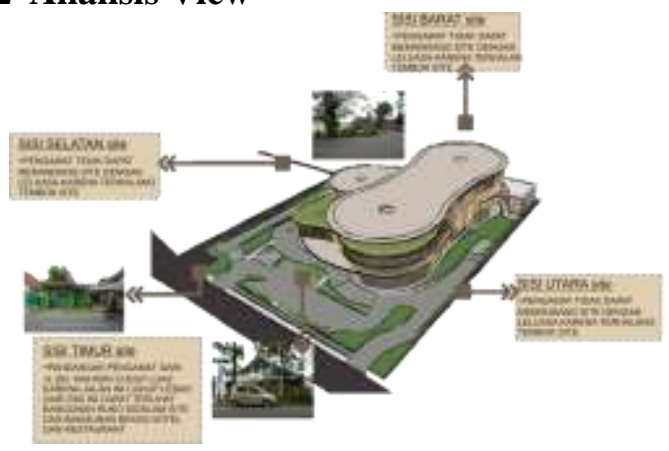

Gambar 5. Analisis View dari Luar Tapak

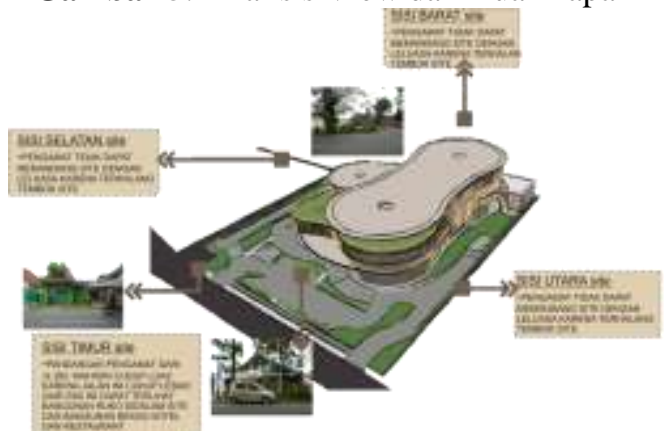

Gambar 6. Analisis View dari Dalam Tapak

Dari analisis di atas didapatkan respon desain yaitu :

Orientasi bangunan menghadap ke arah timur (Jl. Dr. Wahidin). Pengolahan Fasad yang menarik diolah pada sisi timur, selatan, dan utara bangunan.

\subsubsection{Analisis Pemintakatan (Penzoningan)}

Pemintakatan berdasarkan sifat kegiatan dan keadaan dalam tapak dilakukan sebagai acuan dalam penataan peruangan, namun tetap memperhatikan pengaruh psikologi pada penggunanya.

1. Tujuan: Menentukan mintakat (zoning) berdasarkan sifat kegiatan dan keadaan pada tapak.

2. Dasar pertimbangan: analisis peruangan, analisis pengolahan tapak, analisis struktur.

3. Proses analisis: persyaratan ruang, berdasarkan kelompok kegiatan dan analisis pengolahan tapak.

\begin{tabular}{|c|c|c|}
\hline & & $\begin{array}{l}\text { menjadi } \\
\text { pertimbangan } \\
\text { utama } \\
\text { Pencahayaandan } \\
\text { penghawaan alami } \\
\text { penting }\end{array}$ \\
\hline $\begin{array}{l}\text { Pelayanan } \\
\text { Medik }\end{array}$ & $\begin{array}{l}\text {-Pelayan } \\
\text { Medik IGD } \\
\text {-Pelayanan } \\
\text { Medik } \\
\text { Klinik } \\
\text { Khusus } \\
\text {-Pelayanan } \\
\text { Medik Lab. } \\
\text { Klinik } \\
\text { Mahasiswa }\end{array}$ & $\begin{array}{l}\text { Pencapaian telihat } \\
\text { Pencahayaan dan } \\
\text { penghawaan alami } \\
+ \text { buatan }\end{array}$ \\
\hline Penunjang & $\begin{array}{l}\text { Penunjang } \\
\text { medis } \\
\text { Penunjang } \\
\text { non medis }\end{array}$ & $\begin{array}{l}\text { Pencapaian } \\
\text { terlihat } \\
\text { Pencahayaan dan } \\
\text { penghawaan alami } \\
+ \text { buatan } \\
\text { Dapat dijangau } \\
\text { dari segala arah }\end{array}$ \\
\hline Pendidikan & $\begin{array}{l}\text { Fasilitas } \\
\text { praktik dan } \\
\text { kuliah }\end{array}$ & $\begin{array}{l}\text { Pencahayaan dan } \\
\text { penghawaan alami } \\
+ \text { buatan } \\
\text { Dapat dijangkau } \\
\text { dari segala arah } \\
\text { Pengaksesan } \\
\text { terpantau } \\
\text { Tingkat } \\
\text { kebisingan kecil }\end{array}$ \\
\hline Pengelola & & $\begin{array}{l}\text { Pencahayaan dan } \\
\text { penghawaan alami } \\
+ \text { buatan } \\
\text { Pengaksesan } \\
\text { terpantau }\end{array}$ \\
\hline
\end{tabular}

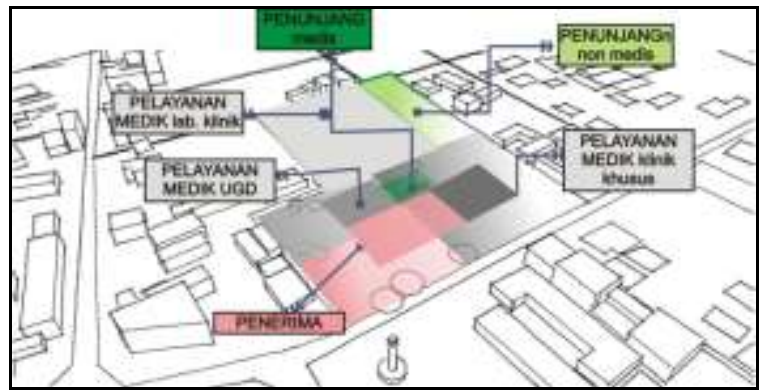

Gambar 7. Hasil Pemintakatan Horizontal Akhir

Tabel 2. Persyaratan Ruang

\begin{tabular}{|c|c|c|}
\hline $\begin{array}{c}\text { MINTA } \\
\text { KAT } \\
(\text { ZONING })\end{array}$ & $\begin{array}{c}\text { KEL. } \\
\text { RUANG }\end{array}$ & PERSYARATAN \\
\hline Penerima & Penerima & $\begin{array}{l}\text { Pencapaian mudah } \\
\text { dari/keluar tapak }\end{array}$ \\
\hline
\end{tabular}




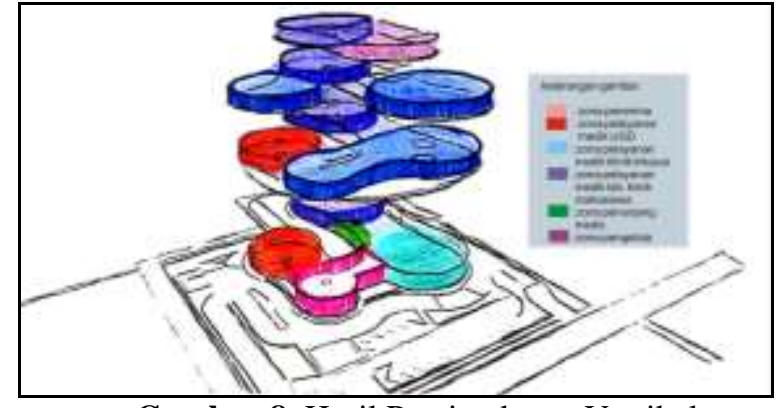

Gambar 8. Hasil Pemintakatan Vertikal Akhir

\subsection{Analisis Konsep Bangunan}

Merumuskan suatu konsep yang dapat mengarahkan masyarakat agar tidak merasa takut untuk masuk ke dalam rumah sakit dan untuk mengurangi potensi takutnya seseorang akan perawatan gigi dan mulut.

\subsubsection{Analisis Berdasarkan Indra Penglihatan}

a. Bentuk Massa Bangunan

Pendekatan bentuk dasar massa mampu merespon aspek-aspek psikologis bagi seluruh pengguna bangunan baik pasien maupun mahasiswa dan karyawan, untuk mendapatkan kenyamanan dengan pertimbangan analisa pada pembahasan sebelumnya yaitu dapat mengatasi masalah-masalah yang menimbulkan ketidaknyamanan psikis, seperti pencapaian, kebisingan, potensi view, iklim, dsb. Dengan demikian bentuk dasar massa yang dipilih adalah bentuk lingkaran memiliki efek pandang luas, dilihat dari aspek psikologis bentuk, lingkaran tidak memiliki sudut, pandangan tidak terhalang, dianggap lebih efektif. Bentuk lingkaran digunakan hanya pada massa utama bangunan dan tidak digunakan pada bentuk ruangan di dalam bangunan Karena bentuk lingkaran pada sebuah ruang kecil dan tertutup dianggap tidak efektif. Untuk itu ruangan di dalam bangunan menggunakan bentuk gabungan antara lengkung dan persegi untuk memaksimalkan ruangan. b. Gubahan dan Tata Massa

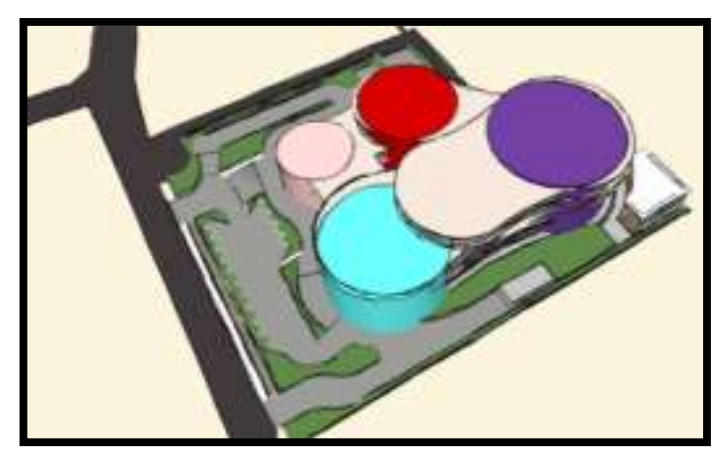

Gambar 9. Gubahan Massa

Untuk kemudahan maka sistem tata massa yang digunakan adalah sistem tata massa gabungan, dikarenakan terdiri dari banyak massa, maka diperlukan space penyatu yang berfungsi sebagai elemen pengikat massa dalam tapak. Dengan sistem tata massa gabungan, maka antar kelompok ruang perlu pemisahan atau penggabungan. Hal ini didasarkan pada pola hubungan ruang, pemintakatan akhir jenis kegiatan dan pelaku kegiatan.

Pada fasad bangunan diolah dengan elevasi yang berbeda beda untuk menimbulkan kesan yang menarik agar pengunjung merasa diterima dan penggunaan elemen sun shading yang menggunakan olahan menyerupai kayu untuk menimbulkan kesan hangat dan mengurangi kesan mengerikan dari rumah sakit. Penggunaan bentuk lingkaran yang tidak bersudut juga membantu untuk mrnciptakan suasana yang tidak kaku dan mengalirkan sirkulasi pengguna bangunan.

c. Tata Ruang Bangunan

1) Tata Ruang Luar Bangunan

Warna coklat dipilih sebagai dominasi bangunan untuk memberikan kesan netral, hangat, serta kesan nyaman dan menerima seperti berada di lingkungan rumah sehingga meninggalkan kesan mengerikan dari rumah sakit. Selain itu juga 
warna coklat adalah warna netral yang dapat diterima oleh semua orang karena merupakan warna alam. Warna coklat dipilih karena RSGMP UMS adalah bangunan dengan fungsi ganda selain sebagai fasilitas kesehatan masyarakat juga sebagai fasilitas pendidikan. Sehingga sebaiknya menggunakan warna yang dapat diterapkan pada kedua fungsi bangunan tersebut.

Tabel 2. Warna

\begin{tabular}{|c|c|c|c|}
\hline $\begin{array}{c}\text { Jenis \& } \\
\text { Terapi } \\
\text { Warna }\end{array}$ & $\begin{array}{l}\text { Wa } \\
\text { rna }\end{array}$ & $\begin{array}{c}\text { Efek } \\
\text { Psikologi }\end{array}$ & Aplikasi \\
\hline $\begin{array}{l}\text { 1. Coklat } \\
\text { Merupakan } \\
\text { warna alami } \\
\text { dan } \\
\text { menunjukkan } \\
\text { kemurnian } \\
\text { serta } \\
\text { keharmonisa }\end{array}$ & & $\begin{array}{l}\text { Netral, } \\
\text { hangat, } \\
\text { memberi } \\
\text { kesan } \\
\text { nyaman dan } \\
\text { menerima. }\end{array}$ & $\begin{array}{l}\text { Mendom } \\
\text { inasi } \\
\text { tampilan } \\
\text { banguna } \\
\text { n sebagai } \\
\text { nuansa } \\
\text { (alternati } \\
\text { f 1) }\end{array}$ \\
\hline $\begin{array}{l}\text { 2. Ivory } \\
\text { Menunjukkan } \\
\text { kepolosan, } \\
\text { keleluasaan } \\
\text { pandangan }\end{array}$ & & $\begin{array}{l}\text { Pucat, netral, } \\
\text { bersih, jika } \\
\text { terlalu muda } \\
\text { akan } \\
\text { menimbulka } \\
\text { n silau }\end{array}$ & $\begin{array}{l}\text { Pada } \\
\text { fasade } \\
\text { sebagai } \\
\text { warna } \\
\text { pelengka } \\
\text { p.(alterna } \\
\text { tif 2) }\end{array}$ \\
\hline $\begin{array}{l}\text { 3. Hijau } \\
\text { Merupakan } \\
\text { warna alami } \\
\text { dan } \\
\text { menunjukkan } \\
\text { kemurnian } \\
\text { serta } \\
\text { keharmonisan }\end{array}$ & & $\begin{array}{l}\text { Pengobatan } \\
\text { shock, } \\
\text { menghilangk } \\
\text { an stress, } \\
\text { menyeimban } \\
\text { gkan dan } \\
\text { menstabilka } \\
\text { n energi } \\
\text { tubuh }\end{array}$ & $\begin{array}{l}\text { Mendom } \\
\text { inasi } \\
\text { tampilan } \\
\text { banguna } \\
\text { n sebagai } \\
\text { nuansa } \\
\text { (alternati } \\
\text { f 3) }\end{array}$ \\
\hline $\begin{array}{l}\text { 4. Kuning } \\
\text { Mempengaruhi } \\
\text { intelektual dan } \\
\text { pengambilan } \\
\text { keputusan }\end{array}$ & & $\begin{array}{l}\text { Menstimulasi } \\
\text { konsentrasi, } \\
\text { mengobati } \\
\text { keluhan nyeri } \\
\text { berlebih, dan } \\
\text { juga dapat } \\
\text { mengurangi } \\
\text { keluhan } \\
\text { stress, kejang } \\
\text { obat }\end{array}$ & $\begin{array}{l}\text { Jalur } \\
\text { sirkulasi } \\
\text { dan pintu } \\
\text { masuk }\end{array}$ \\
\hline
\end{tabular}

2) Tata Ruang Luar Bangunan

Suasana ruang dalam dirancang tidak monoton dengan menghadirkan permainan elemen-elemen interior, seperti: dinding dengan warna dan dihiasi elemen-elemen menarik, perbedaan tinggi plafond, dan pada bagian yang berhubungan dengan pelayanan anak-anak diberikan railing yang dihiasi permainan anak-anak, handle pintu yang dibuat dalam bentukbentuk lucu serta perabot khusus bagian anak-anak berbeda dengan bagian orang dewasa yakni dalam skala anak-anak guna tidak menakutkan bagi psikis pasien anak-anak.

Warna pada bagian yang melayani orang dewasa dibuat dengan sebagian besar warnawarna pastel atau dengan intensitas yang rendah, untuk memberikan kesan yang menenangkan dan hangat.

Sedangkan pada bagian anak-anak dibuat warna yang ceria, tidak monoton. Menurut penelitian, anak-anak menyukai warna-warna primer (merah, kuning, biru, hijau) dan oranye. Warna-warna tersebut diatur intensitasnya sehingga tidak terlalu menyolok namun cukup lembut dan tidak membosankan atau juga dapat mengaplikasikan bergambar sesuai dengan karakter anak.

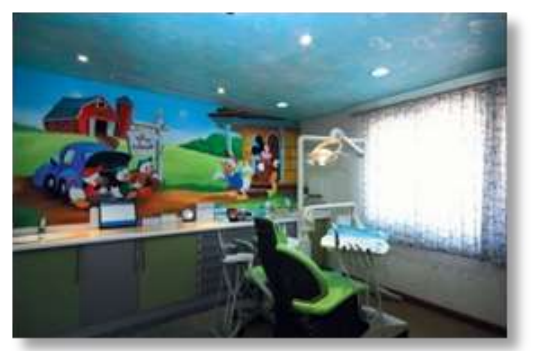

Gambar 10. Contoh Ruang Periksa anak Sumber: www.retalclinic.com 


\subsubsection{Analisis Berdasarkan Indra Pendengaran}

Pada bagian lantai digunakan karpet untuk mengurangi kebisingan. Pada dinding digunakan wallpaper dan gypsum dan pada plafond digunakan acoustic board.

\subsubsection{Analisis Berdasarkan Indra Perasa}

Tabel 3. Penghawaan

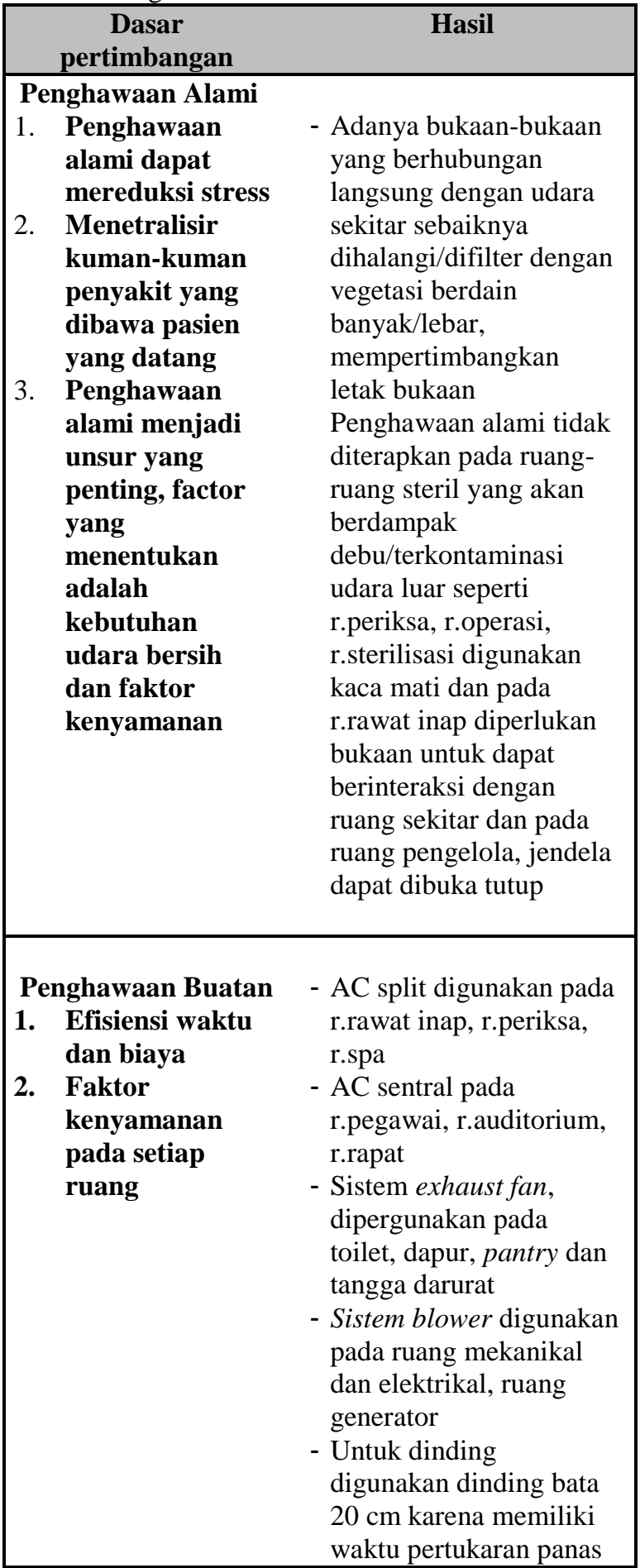

\section{5,5 jam}

\subsubsection{Analisis Berdasarkan Indra \\ Penciuman}

Implikasi terhadap desain dengan system aromaterapi dari tanaman seperti lavender yang dipercaya merupakan tanaman terapi pada healing garden mengandung unsur yang dapat menentramkan pikiran, dan jiwa, mengurangi ketegangan pada syaraf dan juga dapat mengusir nyamuk atau metode pengharum ruangan berbagai aroma yang bekerja otomatis secara berkala di beberapa ruangan tertentu. Serta dengan penghawaan yang cukup pada ruangan-ruangan tertentu misalnya apotik yang menghasilkan bau obat yang sangat menyengat, maka menletakkan apotik berhubungan langsung dengan luar bangunan dan penghawaan secara langsung.

\subsubsection{Analisis Berdasarkan Indra Peraba Tekstur}

Untuk landscaping outdoor digunakan rumput dan finishing bagian luar digunakan pengerasan semen untuk ketenangan dan kesejukan.

\subsection{Analisis Struktur Bangunan \\ 3.7.1 Sub Struktur}

Dengan dasar pertimbangan kondisi jenis tanah, ketinggian bangunan, mengurangi penurunan bangunan dan menghindari pergeseran air pada lapisan tanah teratas.

1) Tiang Pancang

2) Pondasi Batu Kali

\subsubsection{Supper Struktur}

Terdapat beberapa struktur atap yang menghasilkan bentangan besar, yaitu struktur rangka baja dan struktur dak beton bertulang.

\subsection{Analisis Utilitas Bangunan}

1. Sistem Penghawaan dan Pencahayaan

2. Jaringan listrik

3. Jaringan Plumbing 
4. Jaringan Pembuangan

5. Jaringan komunikasi

6. Penanggulangan kebakaran

\section{KESIMPULAN (KONSEP DESAIN)}

Permasalahan fisik dan psikologi yang menghalangi kebutuhan kesehatan bagi pasien penyakit gigi dan mulut dikarenakan belum ada fasilitas khusus yang tersedia dan kurangnya pemahaman pentingnya psikologi pengguna. Oleh karena itu dalam perencanaan dan perancangan Rumah Sakit Gigi dan Mulut Pendidikan UMS dengan Penekanan Psikologi Arsitektur dilengkapi dengan desain ruang yang disesuaikan dengan kegiatan di dalamnya dan fasilitas sarana prasarana yang aksesibel dan khusus sehingga dapat memperbaiki keadaan psikologi para penggunanya. Setiap kelompok kegiatan diletakkan berdasarkan urutan perawatan pasien dan peletakkan area pelayanan dengan kegiatan belajar mengajar dipisahkan dengan perbedaan letak pada bangunan dan akses khusus.

Dari berbagai komponen yang telah di analisis, maka dihasilkan beberapa keputusan desain berupa :

1. Rencana Tapak Kawasan (Lihat Lampiran)

2. Tampak
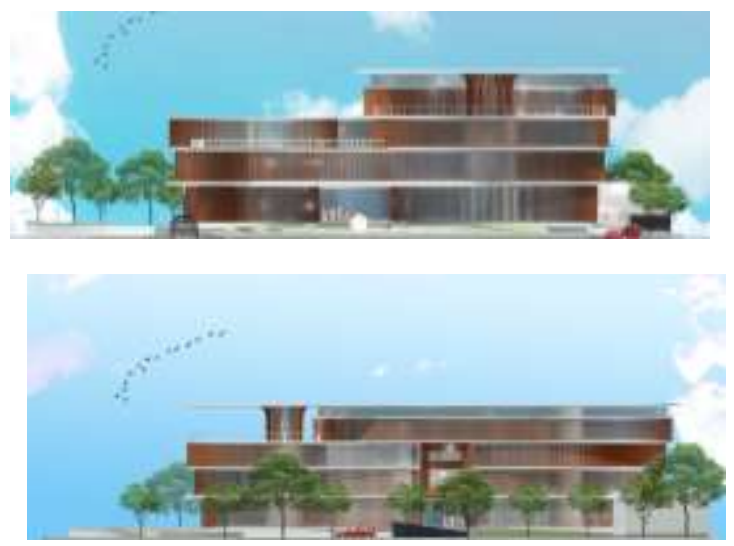

Gambar 11. Tampak
3. Eksterior

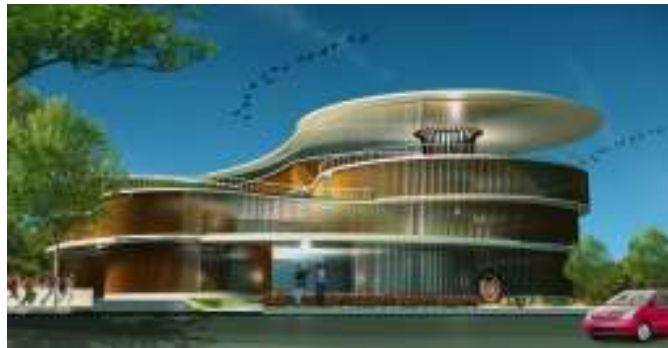

Gambar 12. Eksterior

4. Interior

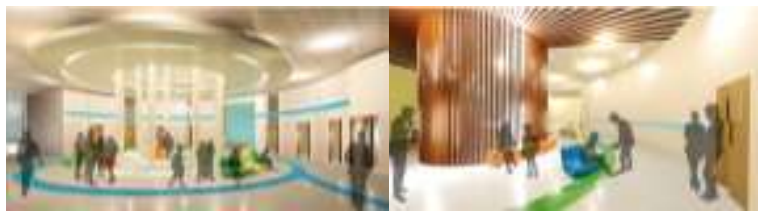

Gambar 13. Ruang Tunggu Klinik Khusus dan Lab. Klinik

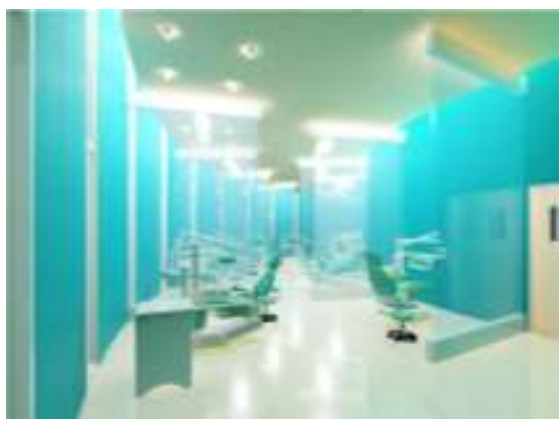

Gambar 14. Lab. Klinik

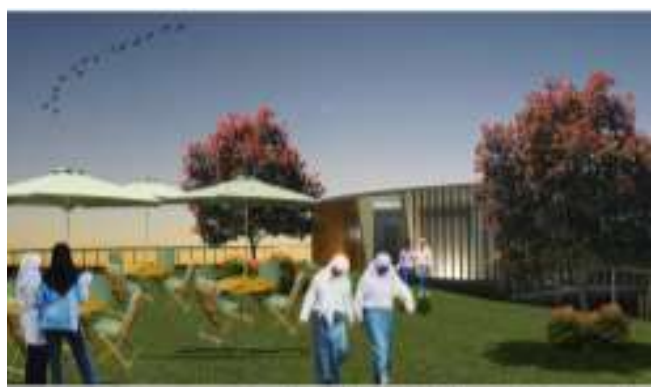

Gambar 15. Roof Garden

\section{REFERENSI}

Konsil Kedokteran Indonesia. 2006. Standar Pendidikan Dokter Gigi. Jakarta

Profil Kesehatan Jawa Tengah Departemen Kesehatan tahun 2012

Profil Kesehatan Kota Surakarta tahun 2012

Http://www.retalclinic.com, diakses tanggal 23 Agustus 2013 


\section{LAMPIRAN}

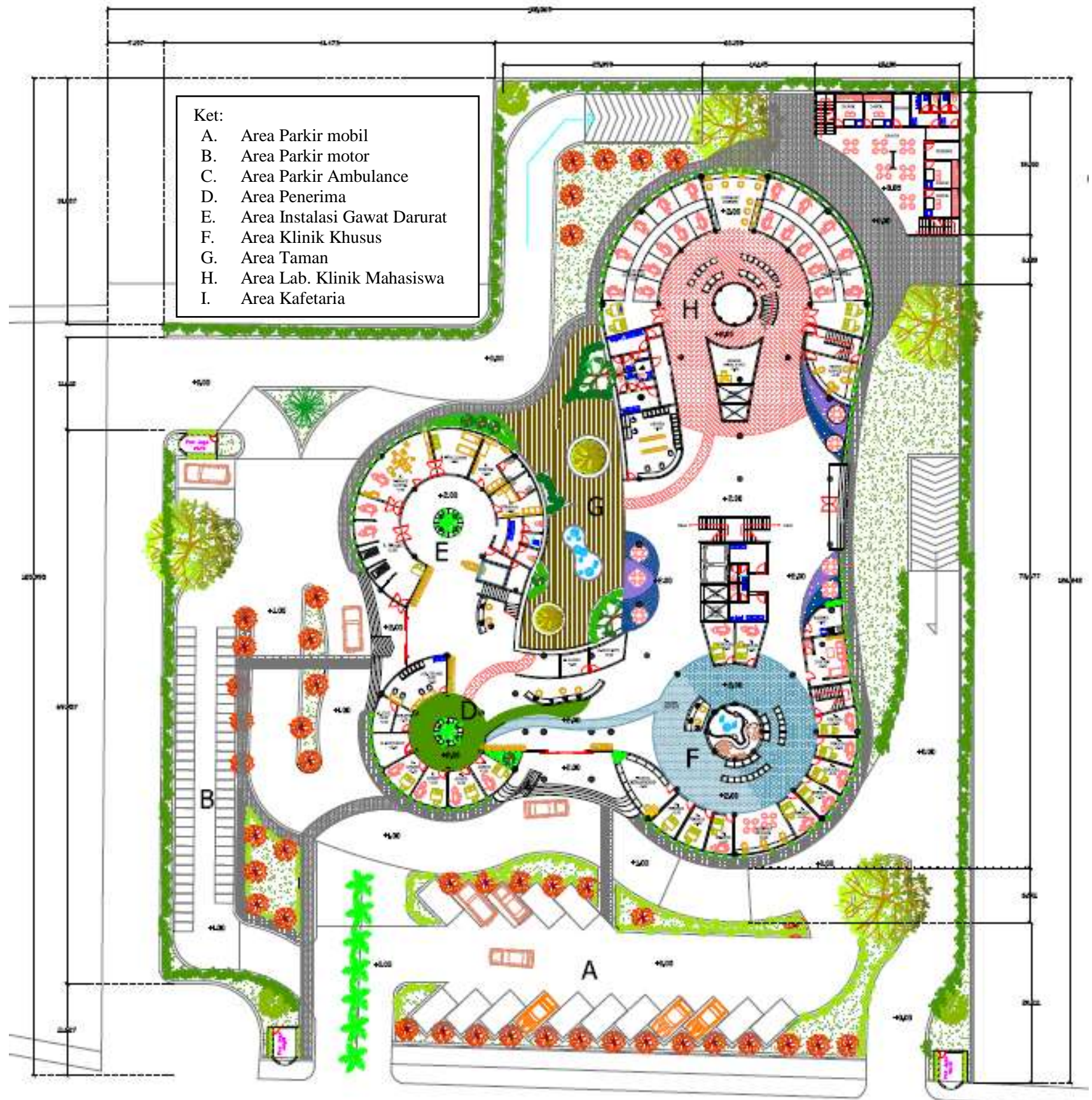

Lampiran. Rencana Tapak 